\title{
SPATIO-TEMPORAL ECOLOGY AND BEHAVIOR OF EUROPEAN GENETS IN SOUTHWESTERN SPAIN
}

\author{
F. Palomares and M. Delibes \\ Estación Biológica Doñana, Consejo Superior de Investigaciones Científicas, \\ Apartado 1056, 41080 Sevilla, Spain
}

\begin{abstract}
Spatio-temporal ecology and behavior of eight European genets, Genetta genetta, were studied over 2 years by radiotracking in southwestern Spain. Genets were exclusively nocturnal, starting activity after sunset and ending before sunrise. Time spent in activity averaged $28 \%$ daily and seemed to be influenced by individual body mass and movement distances. Distance traveled averaged $2.8 \mathrm{~km} /$ day, apparently influenced by individual body mass, distance between resting sites, and habitat composition within home range. Resting sites were thickets $(69 \%, n=546)$ and trees (31\%; mainly hollow trees). Seven individuals were sampled $>70$ days and averaged 16.3 sites for resting. Re-use rate of resting sites was 5.3 times/site. Mean distance between consecutive resting sites was $728 \mathrm{~m}$, although the distance was shorter for young than for adults. Ash stands were the only vegetation type used more than expected, both for resting and for activity; other types were seldom used. Maximum size of home ranges averaged $7.8 \mathrm{~km}^{2}$. Ash stands represented an average of $14 \%$ of the home-range area and seemed to determine shape and size of the home range. Home ranges of adult males and females overlapped greatly, but intrasexual overlap was minimal, suggesting that animals were territorial.
\end{abstract}

Key words: daily activity and movements, Genetta genetta, habitat use, home range, resting sites

In the Carnivora, use of space has been found to be affected by both body mass (Gittleman and Harvey, 1982; Gompper and Gittleman, 1991; McNab, 1963) and dispersion of resources (Macdonald, 1983). As a rule, home-range size should increase with body mass, which has been correlated with an increase in metabolic needs. Additionally, time spent in activity also increases with body mass in mammals (Bunnell and Harestad, 1989). The hypothesis of resource dispersion proposed by Macdonald (1983) predicts that territories have to encompass a minimum total area of key habitats, which will be larger when patches of these key habitats are more dispersed. We studied the spatio-temporal ecology and behavior of European genets, Genetta genetta, in southwestern Spain, testing whether individual body mass and dispersion of relevant habitats influence use of space and activity of genets in Doñana National Park. Spatio- temporal ecology and behavior of European genets have been little studied (Livet and Roeder, 1987; Lode et al., 1991; Palomares and Delibes, 1988). Radiotracking was used to study the activity patterns, daily distances traveled, type and use of resting sites, preferences in use of habitat, size and shape of home range, and spatial relationships between individuals.

\section{Materials AND MeThods}

Study area.-The study took place at Coto del Rey (northern Doñana National Park, southwestern Spain; $37^{\circ} 9^{\prime} \mathrm{N}, 6^{\circ} 26^{\prime} \mathrm{W}$ ), an area characterized by forested areas of pines, Pinus pinea, and eucalyptus (Eucalyptus sp.) with undergrowth mainly of Halimium halimifolium, by small natural streams with mixtures of Fraxinus sp. and Populus alba trees and Pistacia lentiscus and Rubus sp. shrubs predominant, and by associations of exclusively $P$. lentiscus at places with higher ground-water levels. Part of the area 
had been maintained as an autochthonous forest with Quercus suber and undergrowth of $P$. lentiscus and $H$. halimifolium as the more characteristic plant species.

The climate was Mediterranean subhumid, with mild, wet winters and hot, dry summers. Annual rainfall generally ranged between 500 and $600 \mathrm{~mm}$. The coldest and warmest months during the study period were January 1989 and July 1988, with mean temperatures of 9.3 and $26.0^{\circ} \mathrm{C}$, respectively. The study area was flat, with sandy ground; more details can be found in Rogers and Myers (1980).

Trapping and radiotracking.-Genets were captured with boxtraps measuring 1.5 by 0.5 by $0.5 \mathrm{~m}$ and Victor no. 1.5 padded foothold traps between July 1987 and November 1989, following the general trapping method described in Palomares and Delibes (1992a) for capturing Egyptian mongooses, Herpestes ichneumon. After immobilization with a combination of ketamine hydrochloride and xylazine hydrochloride (Palomares, 1993), animals were examined for sex, weight, and age (according to toothwear: adults, with definitive and completely erupted teeth; young, with one or more milk teeth) and equipped with radiocollars containing tip switches (Wildlife Materials, Inc., Carbondale, IL; or Biotrack, Wareham, UK).

Each individual was located daily once during daylight, and sometimes (6.2\% of occasion) during the night as well. Additionally, $424-h$ periods, 40 nocturnal periods, and 2 diurnal periods of intensive tracking were undertaken, locating animals hourly. Diurnal locations were made using the homing technique, whereas nocturnal locations. were determined by triangulation (Mech, 1983), usually from distances varying between 100 and $300 \mathrm{~m}$ from the animals. Activity, spatial location, characteristics of resting sites during daylight, and type of vegetation used were recorded for each location.

Data analyses.-Daily activity patterns were studied by tabulating the percentage of active locations at each hourly interval, using data from the periods of intensive tracking (Palomares and Delibes, 1991a). From these periods, an estimate of the daily time spent in activity (percentage of active locations with regard to the 24-h period) also was obtained. Daily distance traveled was obtained by adding the shortest distances between consecutive hourly locations in the periods of intensive tracking.
Diurnal resting sites were described according to their external characteristics (e.g., thickets and trees). We also calculated the re-use rate of resting sites (total number of resting periods divided by the number of different resting sites) and the linear distance between consecutively used resting sites.

Eleven habitats or vegetation types, all easily distinguished in the field by vegetative and cover characteristics, were considered: ash stands; autochthonous forest; lentiscus; matorral; pine forest; eucalyptus; rushes; pastureland; marsh; meadows; cereal crops. More details can be found in Palomares and Delibes (1993).

Habitat use was independently analyzed for locations indicating activity or resting (as recommended by Palomares and Delibes, 1992b), and habitat diversity in each period was estimated by the Levins (1968) index (B). Because triangulation errors could misclassify the true habitat used by genets during activity (see $\mathrm{Ku}$ feld et al., 1987; Nams, 1989; White and Garrot, 1986), the study area was subdivided into grids 100 by $100 \mathrm{~m}$ in size, and each location was assigned the predominant vegetation type within the corresponding grid.

Preference or avoidance of each vegetation type was determined by the method described in Neu et al. (1974), using chi-square analysis and Bonferroni corrections. Vegetation types used more or less frequently $(P<0.05)$ than available for genets were considered preferred or avoided, respectively. Availability of each vegetation type was estimated inside a composite home range (delineated by the minimum-convex-polygon method-Hayne, 1949) of all radiotracked genets. Vegetation types were interpreted from aerial photographs and ground inspection, and availabilities were estimated by using a digitizer and RANGES software package (Kenward, 1990).

Different estimates of home-range size were calculated: 1) maximum home range, using all the available locations and delineated by the minimum-convex-polygon method (Hayne, 1949); 2) resting home range, calculated from only diurnal resting sites and delineated by the minimum-convex-polygon method; 3) one using all the available occasional locations by the minimum-convex-polygon (removing 5\% outlier fixes) method, and 95\%-harmonic-mean isopleth centering of fixes in 40-by-40 grid cells (Dixon and Chapman, 1980; Spencer and Barrett, 1984). 


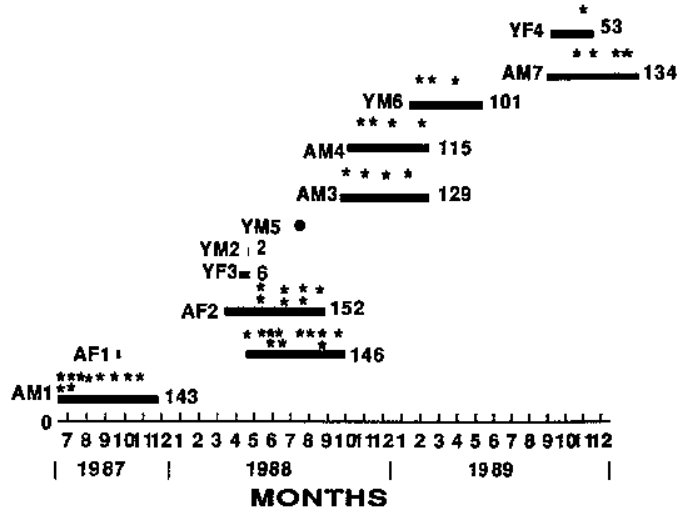

FIG. 1.-European genets trapped and radiotracked between July 1987 and November 1989 at Coto del Rey (Doñana National Park, southwestern Spain). Track periods (lines), days of radiotracking (right of line), and days of intensive tracking (asterisks over the line) are given for each individual; $\mathrm{Y}=$ young, $\mathrm{A}=$ adult, $\mathrm{M}$ $=$ male, and $F=$ female. YM5 was not equipped with a radiocollar.

For reasons of independence (see Reynolds and Laundré, 1990; Swihart and Slade, 1985a), in the last case occasional locations were considered to be those taken on a daily basis and those taken at 2000,2400 , and $0400 \mathrm{~h}$ during the periods of intensive tracking. Maximum and resting home ranges were compared to test whether only locating resting sites was a suitable estimate of area used by animals. The minimumconvex-polygon method was chosen in both cases because it is less sensitive to the use of autocorrelated data (the case when using all available locations) than probabilistic models (Swihart and Slade, 1985b). The 95\%-minimumconvex-polygon and $95 \%$-harmonic-mean methods also were used because both reduced the disadvantages of including peripheral fixes and frequently were used in studies of telemetry (Harris et al., 1990). Estimates were determined using the RANGES software package (Kenward, 1990). Habitat composition inside each individual's home range was measured using the same package and the $95 \%$-minimum-convex-polygon estimate.

Results are presented by classes of individuals (adult males, adult females, and young), and differences were tested using nonparametric statistics (Siegel, 1956). The individual generally was considered the sampling unit and the mean was used when more than one value was available per individual to avoid pseudoreplication (Hurlbert, 1984). Nevertheless, when between-individual differences seemed important, the number of cases was used as the sampling unit, bearing in mind that the reported significant values might be biased. Seasonal differences were not analyzed because data were not always available for each season and class of individual. The effect of individual body mass on the spatio-temporal aspects studied, and the possible interactions between them, were inferred using correlation analyses.

\section{RESULTS}

Study population.--Eleven genets (four adult males, two adult females, two young females, and three young males) were trapped with box-traps $(n=8)$ or padded foothold traps $(n=3)$ a total of 25 times between July 1987 and July 1989. Ten genets had radiotransmitters attached, but one young male was killed by a dog and the radiocollar of a young female stopped working 2 and 6 days after being tagged, respectively. The remaining eight individuals were radiotracked for an average of 122 days $(S D=32$, range $=53-152$; Fig. 1). Radiotracking periods from two (a young male and an adult male) of these eight individuals ended when they were killed by a dog and by an Iberian lynx, $\mathrm{Fe}$ lis pardina, respectively.

Adult, mean body mass was $1.90 \mathrm{~kg}$ ( $S D$ $=0.82$, range $=1.80-2.00, n=4$ ) for males and $1.87 \mathrm{~kg}(S D=0.13$, range $=$ $1.78-1.96, n=2$ ) for females. One adult female was pregnant when trapped a second time on 18 April (weight $=1.85 \mathrm{~kg}$ ); after 45 days, she gave birth to three young. The young were found dead 6 days later.

Activity.-Genets were exclusively noc turnal, starting and ending activity after sunset and before sunrise, respectively (Fig. 2). Each class of individual presented similar patterns of activity (Kendall rank correlation coefficient, $W=4.42, P<$ 0.0001 ). Genets always were detected active or outside their resting sites in the hours following sunset and preceding sun- 
rise ( $n=44$ nights). Onset of activity showed a regular pattern, as genets were detected active in the 1 st $(27.3 \%)$ or 2 nd $(70.5 \%)$ hour following sunset. The cessation of activity was less predictable. Genets mainly ceased to be active 1 $(31.8 \%)$ or $2(31.8 \%) \mathrm{h}$ before sunrise. On some days, activity ended $3(20.5 \%)$ or 4 $(13.6 \%)$ h before sunrise.

At no time during the 6 days of intensive tracking (70 locations) were genets active during daylight. However, daylight activity was detected on $2.5 \%$ of occasional locations $(S D=2.1, n=8)$. There were significant differences between classes of individuals (Kruskal-Wallis test, $H=6, P=$ 0.0498 ), with young more active during daylight ( $\bar{X}=5.5 \%, S D=0.2, n=2)$ than females ( $\bar{X}=2.8 \%, S D=1.6, n=2)$ and males $(\bar{X}=0.9 \%, S D=0.6, n=4)$. Diurnal activity detected during occasional locations could be a result of disturbance by observers near the resting site.

The mean activity time was $28.4 \%$ ( $S D$ $=5.3, n=8$; Table 1). Values were similar among individuals $(H=3.17, P=0.205$; Table 1). Daily activity time seemed to be influenced by individual body mass (Spearman rank correlation coefficient, $r_{\mathrm{s}}=0.64$, $P=0.089, n=8$ ), distance between consecutively used resting sites $\left(r_{\mathrm{s}}=0.86, P\right.$ $=0.023, n=8$ ), and daily distance traveled $\left(r_{\mathrm{s}}=0.67, P=0.078, n=8\right)$.

Daily movements. - Distance traveled averaged $2.78 \mathrm{~km} /$ day $(S D=1.78, n=8$; Table 1). Young seemed to travel shorter distances than adults (Table 1), but significant differences were not detected either by using individuals as the sampling unit (Kruskal-Wallis test, $H=1.79, P=0.408$ ) or by using days as the sampling unit (analysis of variance, ANOVA; $F=1.148 ; d f$. $=2,41 ; P=0.327$ ). Nevertheless, this was probably an artifact of the small sample, because a strong correlation was detected between daily distance traveled and linear distance between consecutive resting sites (Spearman rank correlation coefficient, $r_{\mathrm{s}}=$ $0.81, P=0.032, n=8$ ), and significant

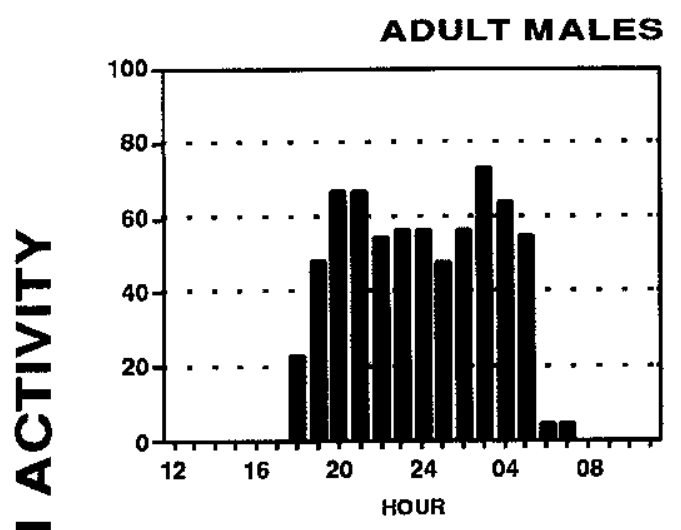

ADULT FEMALES
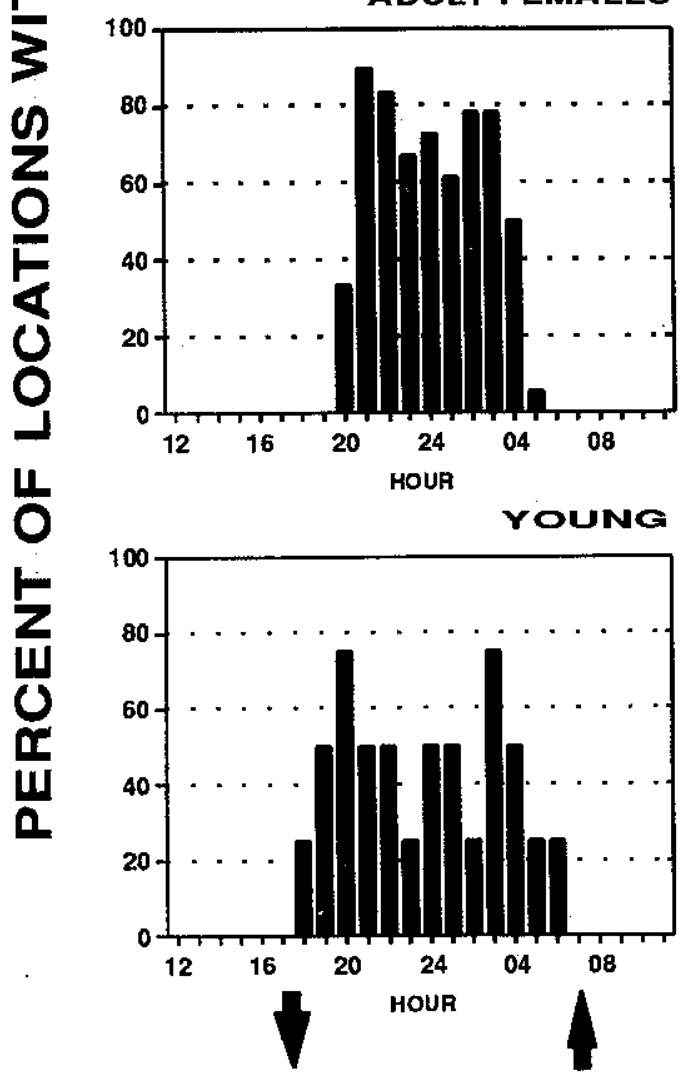

FIG. 2.-Daily activity patterns of adult male ( $n=4,22$ days), adult female ( $n=2,28$ days), and young ( $n=3,4$ days) genets at Coto del Rey (northern Doñana National Park, southwestern Spain). Arrows indicate the approximate time of sunset and sunrise. 
TABLE 1.-Daily activity time, re-use rates of resting sites, distance between consecutively used resting sites, and daily distance traveled for adult female, adult male, and young European genets in the Coto del Rey (Doñana National Park, southwestern Spain).

\begin{tabular}{|c|c|c|c|c|}
\hline Parameter & Females & Males & Young & Overall \\
\hline \multicolumn{5}{|l|}{ Daily activity time (\%) } \\
\hline$n$ & 2 & 4 & 3 & 9 \\
\hline No. of days & 28 & 22 & 4 & 44 \\
\hline \multicolumn{5}{|l|}{ Activity of time } \\
\hline $\bar{x}$ & 26.3 & 30.9 & 25.7 & 28.4 \\
\hline$S D$ & 4.7 & 5.9 & 5.0 & 5.3 \\
\hline Range & $22.9-29.6$ & $23.3-37.5$ & $22.1-29.2$ & $22.1-37.5$ \\
\hline \multicolumn{5}{|c|}{ Daily distance travelled $(\mathrm{km})$} \\
\hline$n$ & 2 & 4 & 2 & 8 \\
\hline No. of days & 28 & 22 & 4 & 44 \\
\hline \multicolumn{5}{|l|}{ Distance } \\
\hline $\bar{X}$ & 2.61 & 3.52 & 1.48 & 2.78 \\
\hline$S D$ & 0.76 & 2.25 & 0.84 & 1.78 \\
\hline Range & $2.07-3.14$ & $1.18-6.56$ & $0.89-2.07$ & $0.89-6.56$ \\
\hline \multicolumn{5}{|l|}{ Re-use rates } \\
\hline$n$ & 2 & 4 & 3 & 9 \\
\hline No. of days & 244 & 326 & 112 & 682 \\
\hline No. of resting sites & 39 & 59 & 24 & 122 \\
\hline \multicolumn{5}{|l|}{ Re-use rates } \\
\hline $\bar{x}$ & 6.5 & 6.0 & 3.4 & 5.3 \\
\hline$S D$ & $1: 7$ & 1.9 & 1.3 & 2.0 \\
\hline Range & $5.3-7.7$ & $4.1-8.6$ & $2.0-4.4$ & $2.0-8.6$ \\
\hline \multicolumn{5}{|c|}{ Distance $(\mathrm{m})$ between consecutive resting sites } \\
\hline$n$ & 2 & 4 & 2 & 8 \\
\hline No. of cases & 210 & 227 & 80 & 517 \\
\hline \multicolumn{5}{|l|}{ Distance } \\
\hline $\bar{X}$ & 728 & 901 & 381 & 728 \\
\hline$S D$ & 257 & 387 & 124 & 357 \\
\hline Range & $546-910$ & $429-1372$ & $293-468$ & $293-1372$ \\
\hline
\end{tabular}

differences were detected between classes of individuals.

Distance traveled was positively correlated with individual body mass $\left(r_{\mathrm{s}}=0.67\right.$, $P=0.078, n=8$ ) and with distance between consecutively used resting sites $\left(r_{\mathrm{s}}\right.$ $=0.81, P=0.032, n=8$ ) and was negatively correlated with the quantity of preferred habitat (ash stands) in the home ranges (delineated by the $95 \%$ minimum convex polygon; $r_{\mathrm{s}}=-0.71, P=0.059$, $n=8$ ).

Resting sites.-Genets were detected in two general types of diurnal resting sites: thickets $(68.7 \%)$ and trees $(31.3 \%)$. Use of thickets probably was overestimated because, on several occasions, there were surrounding trees; therefore, we could not be sure which site was used. Thickets $(n=$ 375) mainly were comprised of Rubus sp. $(55.7 \%)$ and mixed thickets of different shrubs and climbing plants $(29.3 \%)$. The use of Tamarix sp. and $P$. lentiscus shrubs was also detected ( 8 and $7 \%$, respectively). Trees $(n=171)$ mainly comprised ash $(72.5 \%)$ and dead trunks upon the ground (24\%). When using trees, genets always were inside hollows, with the exception of 


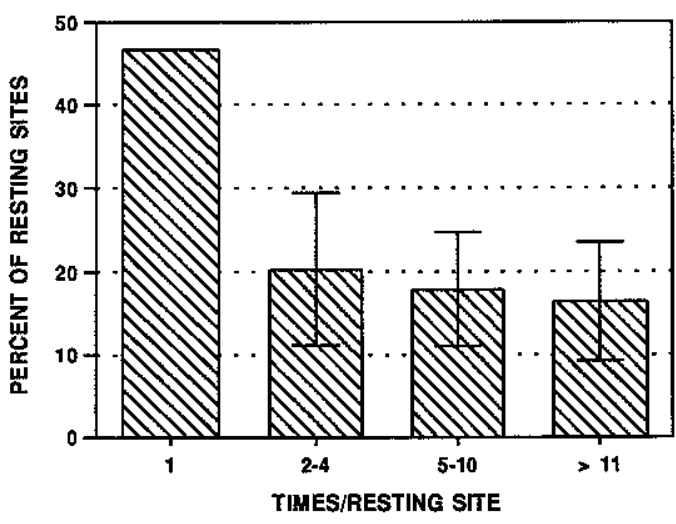

FIG. 3.-Mean $( \pm 1 S D)$ use of diurnal resting sites of eight European genets sampled $>30$ times at Coto del Rey (Doñana National Park, southwestern Spain). Ordinates show the percentage of resting sites where each genet was located one or more times.

one occasion when a male was observed upon a branch.

Nine individuals used 122 nocturnal resting sites on 682 occasions (Table 1). There was a significant positive correlation between number of sampled days and number of resting sites used per individual $\left(r^{2}=\right.$ $0.68, P=0.006 ; \mathrm{Y}=3.26+0.141 \mathrm{X})$; however, excluding from the calculation the two least-sampled individuals $(n=6$ and $31)$, the correlation was not significant $\left(r^{2}\right.$ $=0.18, P=0.3380$ ), suggesting that sample size was adequate for the remaining seven individuals (all of them sampled $>70$ days). The mean number of resting sites was $16.3(S D=4.5$, range $=10-23)$ for these individuals.

The mean number of days per resting site, or re-use rate, was $5.3(S D=2.0, n=$ 9 ; Table 1). Differences in re-use rates between classes of individuals were not sig nificant ( $H=4.44, P=0.108$; Table 1$)$. Throughout the 46 periods of intensive tracking, genets never used more than one resting site in the same day.

By analyzing in greater detail the patterns of use of diurnal resting sites by the eight most sampled ( $n>30$ days) individuals, we found that between 5 and 12 rest-

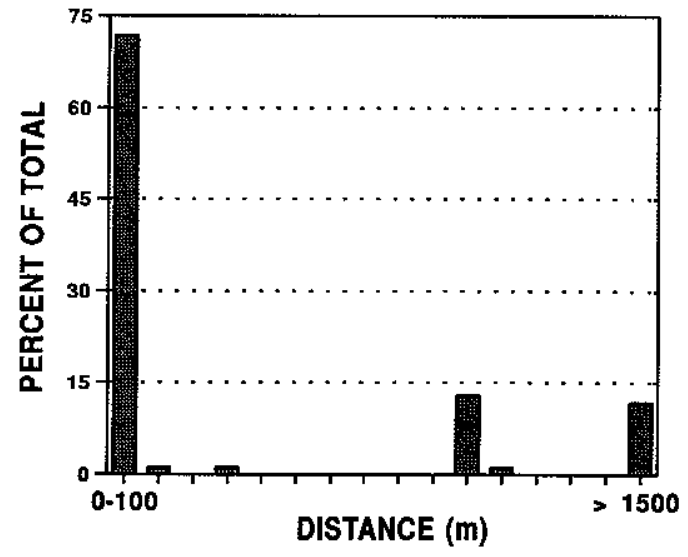

FIG. 4.-Distribution of distances (at 100-m intervals except those $>1,500 \mathrm{~m}$, which are grouped) between consecutively used resting sites $(n=85)$ of an adult male chosen as an example at Coto del Rey (Doñana National Park, southwestern Spain).

ing sites were used only once $(\bar{X}=45.4 \%$, $S D=0.0$ ), and between one and four were used $>11$ times $(\bar{X}=16.4 \%, S D=7.2$; Fig. 3). All individuals spent $>50 \%$ of days in only a few sites: three individuals, three sites; five individuals, two sites.

The mean distance between consecutively used, diurnal resting sites was $728 \mathrm{~m}$ ( $S D$ $=357, n=8$; Table 1 ). Minimum and maximum distances detected for any individual were 0 and $4,401 \mathrm{~m}$, respectively. Significant differences between classes of individuals were not detected $(H=2.83, P=$ 0.242 ), despite the fact that distances between resting sites seemed to be shorter for young (Table 1). By using the number of cases as the sampling unit (data were transformed to $\log (x+0.1)$ ), differences between young and adults were significant (ANOVA; $F=3.89 ;$ d.f. $=2,514 ; P=$ $0.021)$. Distances between resting sites were either short $(0-100 \mathrm{~m})$ or very long (>900 m; Fig. 4), giving a distribution with two or three peaks, which did not always coincide among individuals for distances $>500 \mathrm{~m}$.

Habitat use.-Genets mainly used ash stands both during activity $(56.3 \%, n=112$ 
TABLE 2.--Availability of each vegetation type inside a composite home range of genets in Coto del Rey, and percentage of use of each vegetation type during the activity and the diurnal resting. Vegetation types used more or less than expected are indicated with $a+$ or - , respectively. The number of locations for each activity period is given in parentheses.

\begin{tabular}{lccc}
\hline & Avail & \multicolumn{2}{c}{ Use (\%) } \\
\cline { 3 - 4 } \multicolumn{1}{c}{ Habitat } & ability & Activity & DiurnaI \\
type & $(\%)$ & $(n=112)$ & $(n=737)$ \\
\hline Autochthonous & & & \\
$\quad$ forest & 12.3 & -5.4 & $-3.7^{* * * *}$ \\
Ash stands & 6.1 & $+56.3^{* * * *}$ & $+76.4^{* * * *}$ \\
Lentiscus & 7.0 & +7.1 & +9.3 \\
Pine forest & 38.8 & $-7.1^{* * * *}$ & $-1.8^{* * * *}$ \\
Eucalyptus & 18.2 & -8.9 & $-8.3^{* * *}$ \\
Meadows-marsh & 14.8 & $-3.6^{*}$ & $-0.0^{* * *}$ \\
Crops & 2.2 & +3.6 & $-0.1^{* * *}$ \\
Pastureland & 6.1 & +7.1 & $-0.5^{* * * *}$ \\
Matorral & 6.2 & -0.0 & $-0.0^{* * *}$ \\
Rushes & 1.7 & -0.9 & $-0.0^{* * *}$ \\
\hline
\end{tabular}

\footnotetext{
$* P \leq 0.05$.

$* * P \leq 0.01$.

$* * * P \leq 0.001$.
}

locations) and resting $(76.4 \%, n=737$; Table 2). The remaining habitats were seldom used, and pine forests, meadows, and the marsh always were avoided. $P$. lentiscus always was used according to its availability, while other habitats were avoided during resting or used according to their availability during activity (Table 2). Diversity of used habitat was higher during activity ( $B$ $=2.103)$ than during resting $(B=1.175)$. Differences in habitat use among classes of individuals were analyzed using only the data for resting because of the small sample size during activity. Grouping the habitats according to their use (preferred, avoided, and indifferent), significant differences were detected between classes of individuals $\left(\chi^{2}=57.6\right.$, d.f. $=4, P<0.001$; Fig. 5), although this reflected individual differences. Eucalyptus was used only by one female, while autochthonous forest was used exclusively by one young male.

Home-range size and spatial relationships.-Home-range size could be suitably

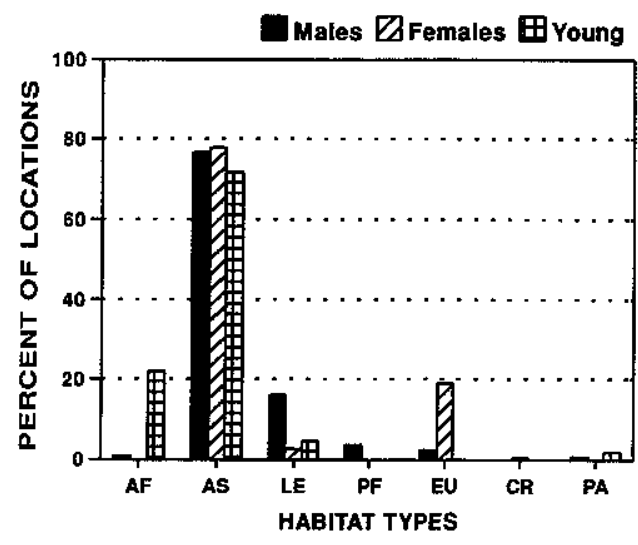

FIG. 5.-Habitat use and preference by adult male, adult female, and young genets at Coto del Rey (northern Doñana National Park, southwestern Spain); AF = autochthonous forest, AS $=$ ash stands, $\mathrm{LE}=$ lentiscus, $\mathrm{PF}=$ pine forest, $\mathrm{EU}=$ eucalyptus, $\mathrm{CR}=$ crops, and $\mathrm{PA}=$ pastureland.

estimated for eight individuals, for which the minimum number of fixes ranged between 36 and 129. Maximum home-range size averaged $7.81 \mathrm{~km}^{2}(S D=3.94$, range $=0.73-14.71$ ), being 1.16 times larger than the home range including only resting sites $\left(\bar{X}=6.54 \mathrm{~km}^{2}, S D=3.11\right.$, range $=0.73$ 11.03). Using only occasional locations, mean home-range sizes calculated using 95\%-minimum-convex-polygon and 95\% harmonic-mean methods were $5.41 \mathrm{~km}^{2}$ $(S D=3.29$, range $=0.33-11.92)$ and 4.03 $\mathrm{km}^{2}(S D=4.03$, range $=0.48-11.09)$, respectively. No significant correlation was detected between any estimate of homerange size and number of fixes used $\left(r_{\mathrm{s}}=\right.$ $0.19,0.07,0.12$ and $-0.24, P>0.50$, for a home-range maxima, resting home range, 95\% minimum convex polygon and $95 \%$ harmonic mean, respectively), suggesting that sample sizes did not influence the estimate of home-range size. As a rule, homerange sizes were similar for adult males and females (mean 95\% minimum convex polygon $=6.18$ and $5.79, S D=3.86$ and 1.01 , for males and females, respectively). One young male had a home-range size similar to that of adults $\left(6.63 \mathrm{~km}^{2}\right.$ for the $95 \% \mathrm{~min}$ - 
imum convex polygon), whereas that of one young female was much smaller $\left(0.33 \mathrm{~km}^{2}\right)$.

Habitat composition inside home ranges consisted of a low percentage $(\bar{X}=14 \%$, $S D=17.7$, range $=2.8-56.9$ ) of the preferred vegetation type (ash stands) and larger areas $(\bar{X}=43.1, S D=19.0$, range $=$ 13.8-63.7) of avoided habitats (pine forest and meadows-marsh). Habitats indifferently used (lentiscus) represented $11.3 \%$ on average $(S D=10.7$, range $=2.5-25.2)$. Spatial dispersion of ash stands seemed to determine size and shape of home ranges, as the corners and limits of home ranges coincided with patches of this vegetation type, especially for the individuals inhabiting the western portion of the study area (Fig. 6). Additionally, there was a strong correlation between home-range size and daily distance traveled by genets $\left(r_{\mathrm{s}}=0.74, P=0.051, n\right.$ $=8$ ).

Home ranges of adult males and females overlapped greatly (Fig. 6). However, adults of the same sex seemed to be territorial, because little home-range overlap was observed (Fig. 6) and different individuals of the same sex were never trapped inside the home ranges of the radiotracked adults. The young female's home range was situated inside the home range of adults, whereas the young male traveled in areas little used by other genets.

Considering the observed intrasexual territoriality for both sexes, the great overlap between genets of different sex, and the mean adult home-range size (using the 95\%-minimum-convex-polygon method), the minimum density of adult genets was estimated as $0.33 / \mathrm{km}^{2}$. Young genets overlapped their home ranges with that of adults, and at least two young were captured between April and June of 1988 inside the home range of adults using the western portion of the study area, thereby making total density ca. $0.67 / \mathrm{km}^{2}$.

\section{Discussion}

In our study area, the density of genets can be considered low. Desmet and Ham-
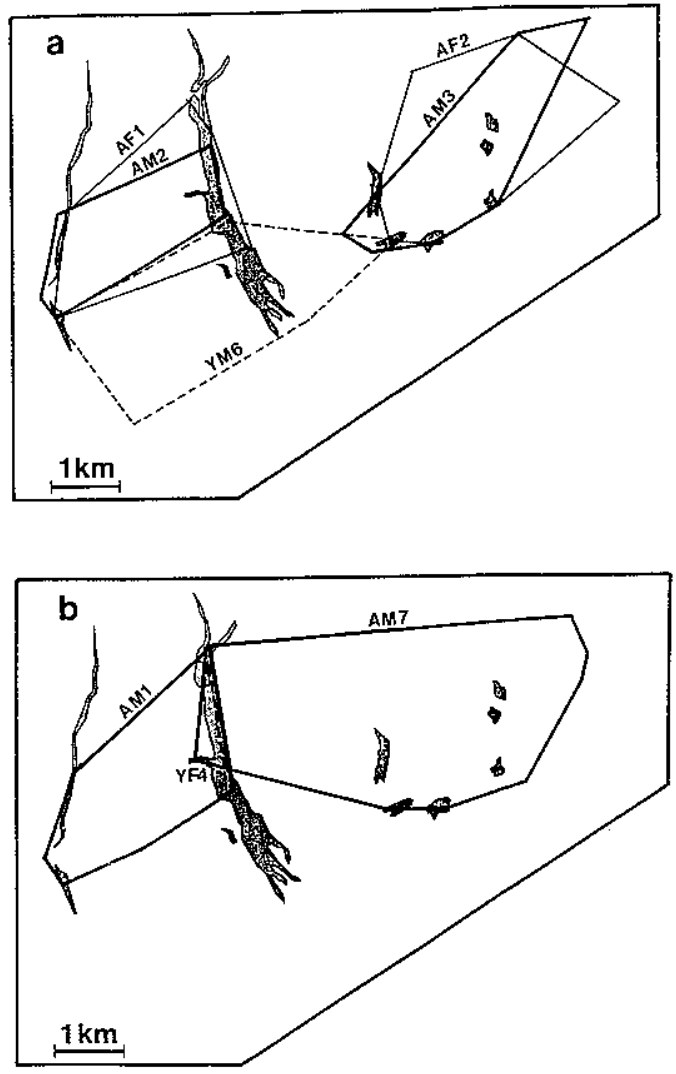

Fig. 6.-Spatial distribution of home ranges (95\% minimum convex polygon) of eight European genets at Coto del Rey (northern Doñana National Park, southwestern Spain). a) Individuals radiotracked between March 1988 and April 1989 , and b) individuals radiotracked in other times (see Fig. 1); $\mathrm{Y}=$ young, $\mathrm{A}=$ adult, $\mathrm{M}=$ male, and $\mathrm{F}=$ female. Shaded areas correspond to ash-stand patches.

dine (1988) captured seven individuals during 10 days of trapping in an area of only 3 ha in Algeria, and Waser (1980) reported densities of $1.5 / \mathrm{km}^{2}$ for a similar species, Genetta tigrina, in the Serengeti. Nevertheless, the density of genets in Donana $\mathrm{Na}$ tional Park may be higher than it was 30 years ago, when Valverde (1960) considered this carnivore almost absent. This increase may be related to changes in management practices, including periodic burning, which encouraged the growth of dense scrubland (Delibes, 1987) and the in- 
crease of populations of small mammals (Kufner and Moreno, 1989), both favoring genets, which mainly feed on small mammals and use dense vegetation (Palomares and Delibes, 1988, 1991 b).

Activity was exclusively nocturnal, which contrasts with the high degree of diurnal activity observed for a young female in another part of Doñana National Park (Palomares and Delibes, 1988). In that study, lack of cover may have been a factor to consider. In northern Spain, two female genets also were nocturnal (E. Camacho, pers. comm.). All the other species of genets that have been radiotracked exhibited mainly nocturnal activity, although considerable diurnal activity was observed (Fuller et al., 1990; Ikeda et al., 1982, 1983; Maddock and Perrin, 1993).

Great variability has been reported for average daily activity in genets. Our results were similar to those obtained by Kavanau and Ramos (1975) with captive genets, but lower than those reported for free-ranging genets elsewhere (Fuller et al., 1990; Ikeda et al., 1983). Variability in the times of onset and end of activity also have been de-tected in several captive carnivores (including genets) by Kavanau and Ramos (1972).

Little information exists on daily move ments of genets. Livet and Roeder (1987) reported a young female European genet moving $7.5 \mathrm{~km}$ in 1 day, whereas a young female and an adult male moved over greater distances in another part of Doñana $\mathrm{Na}-$ tional Park (Palomares and Delibes, 1988). This was probably as a result of diurnal activity of the young female and dispersal behavior of the male.

Thickets and hollow trees were the resting sites selected by genets. Because genets spent most of their time resting, selection of sites that provide safety from predators (dog and lynxes) and protection from weather was very important. Palomares and Delibes (1988) also reported similar resting sites for two individuals in another part of Doñana National Park, and Fuller et al. (1990) reported the use of large aggregations of shrubs by $G$. maculata, with re-use rates slightly lower (one to three times/site) than those reported here. In our study, re-use rates were high, and distance between consecutively used resting sites mainly followed a bimodal or trimodal distribution around short $(0-100 \mathrm{~m})$ and long $(>500 \mathrm{~m})$ distances. This result can be explained by the preference for ash stands during foraging and resting and the spatial dispersion of this vegetation type in the study area: genets were exploiting the same ash patch for several days, using one or two resting sites within the patch (i.e., distance between resting sites was short). Sometimes they changed patches, and, therefore, the distance between resting sites was long, as ash stand patches were usually far apart (see Fig. 6).

Habitat use was largely restricted to ash stands and $P$. lentiscus associations. Nevertheless, this specificity was higher for resting than for activity, as shown by the diversity index. Fuller et al. (1990) reported a similar pattern of habitat use for resting and activity in G. maculata. Brambles and hollow trees were more abundant in ash stands than in other habitats (pers. obser.). Conversely, diversity and abundance of small mammals and passerines (main prey of genets in Doñana National Park-Palomares and Delibes, 1991b) are probably higher in this vegetation type (Camacho and Moreno, 1989; García et al., 1989). Avoidance by genets of autochthonous forest, apparently suitable habitat, may have been because it is the only habitat used by lynx in the study area (F. Palomares et al., in litt.). Another small carnivore inhabiting the study area, the Egyptian mongoose, similarly avoided this vegetation type ( $\mathrm{Pa}$ lomares and Delibes, 1993).

Home-range size of two young females previously radiotracked in France and Doñana National Park (Livet and Roeder, 1987; Palomares and Delibes, 1988) were similar to that reported here. An adult female in France had a smaller home range (Lode et al., 1991), and the adult male radiotracked by Palomares and Delibes 
(1988) showed a wandering behavior over an area of $50 \mathrm{~km}^{2}$. For $G$. felina (referred to as $G$. genetta), much smaller home ranges than in the present study were found (Ikeda et al., 1983; Waser, 1980). However, Fuller et al. (1990) found similar home ranges for $G$. maculata. The methods used in these studies (feeding sites by Ikeda et al., 1983, and the sightings by Waser, 1980) probably underestimated the actual home ranges of genets, although their results also could be influenced by habitat quality.

Habitat composition of the home ranges of genets in our study area was characterized by low percentages of preferred vegetation and larger areas that were rarely or never used, similar to the finding of Fuller et al. (1990). The spatial distribution and quantity of ash stands seemed to determine shape and extension of home ranges of genets. Hence, one may predict smaller home ranges in habitats of greater quality (i.e., greater quantity and lower dispersion).

\section{RESUMEN}

Se estudió durante dos años usando telemetría la ecología y conducta espaciotemporal de un total de ocho ginetas en el sur-oeste de España. Las ginetas fueron exclusivamente nocturnas, comenzando la actividad después de la puesta del sol, y terminándola antes de la salida del sol. El tiempo medio diario pasado en actividad fue del $28 \%$, y parecía estar influido por el peso corporal de cada individuo y la distancia recorrida diariamente. La distancia media recorrida por día fue de $2,8 \mathrm{~km}$. El peso corporal de cada individuo, la distancia entre madrigueras, y la estructura de la vegetación dentro del área de campeo parecieron influenciar la distancia recorrida diariamente. Las madrigueras fueron marañas de vegetación $(69 \%, n=546)$ y árboles (31\%; principalmente en huecos de árboles). Siete individuos que fueron muestreados mas de 70 días usaron en promedio 16.3 sitios distintos para descansar. Cada madriguera tuvo un re-uso medio de 5.3 veces. La distancia media entre madrigueras usadas consecutivamente fue de $728 \mathrm{~m}$, aunque en jóvenes esta distancia fue más corta que en adultos. Las fresnedas fueron el único tipo de vegetación usado más de lo esperado tanto para descansar como durante la actividad. Los otros tipos de vegetación fueron poco utilizados. El área de campeo máxima fue de $7.8 \mathrm{~km}^{2}$ en promedio. Las fresnedas representaron sobre el $14 \%$ del área de campeo, y parecieron determinar su forma y tamaño. Las áreas de campeo de machos y hembras adultos solaparon casi totalmente, sin embargo el solapamiento fue mínimo intrasexualmente, sugiriendo que los ginetas fueron territoriales.

\section{ACKNOWLEDGMENTS}

The research was supported by Dirección General de Investigación Científica y Tecnológica (project PB87-0405) and Consejo Superior de Investigaciones Científicas, which provided financial support to F. Palomares. J. J. Roeder, E. C. Hellgren, K. Nelson, T. K. Fuller, and an anonymous referee kindly reviewed and provided useful comments on a early version of the manuscript. K. Nelson also reviewed the English version.

\section{Literature Cited}

BunNell, F. L., AND A. S. HARESTAD. 1989. Activity budgets and body weight in mammals. How sloppy can mammals be? Current Mammalogy, 2:245-305. CAMACHO, J., AND S. Moreno. 1989. Datos sobre la distribución espacial de micromamíferos en el Parque Nacional de Doñana. Doñana, Acta Vertebrata, 16:239-245.

DeliBes, M. 1987. Futuro de la gestión de los espacios naturales protegidos: el caso del Parque Nacional de Doñana. Pp. 83-88, in El futuro de la gestión de los recursos naturales renovables en España (Consejo Superior de Investigaciones Científicas, eds.). Madrid, Spain, 119 pp.

Desmet, K., And W. Hamdine. 1988. Densités de genettes (Genetta genetta Linné, 1758) en yeuseraie algérienne. Mammalia, 52:604-607.

Dixon, K. D., AND J. A. Chapman. 1980. Harmonic mean measure of animal activity areas. Ecology, 61: 1040-1044.

Fuller, T. K., A. R. Biknevicius, and P. W. Kat. 1990. Movements and behavior of large spotted genets (Genetta maculata Gray 1830) near Elmenteita, Kenya (Mammalia, Viverridae). Tropical Zoology, 3:13-19.

García, L., J. Calderón, and J. Castroviejo. 1989. Las aves de Doñana y su entorno. Cooperativa Marismas del Rocio, Huelva, Spain, 136 pp. 
Gittleman, J. L., And P. H. Harvey. 1982. Carnivore home-range size, metabolic needs and ecology. Behavioral Ecology and Sociobiology, 10:57-63.

GompPER, M. E., AND J. L. GitTleman. 1991. Home range scaling: intraspecific and comparative trends. Oecologia (Berlin), 87:343-348.

Harris, S., W. J. Cresswell, P. G. Forde, W. J. TreWHELLA, T. WOOLLARD, AND S. WRAY. 1990. Homerange analysis using radio-tracking data-a review of problems and techniques particularly as applied to the study of mammals. Mammal Review, 20:97123.

HAYNE, D. W. 1949. Calculation of size of home range. Journal of Mammalogy, 30:1-18.

Hurlbert, S. H. 1984. Pseudoreplication and the design of ecological field experiments. Ecological Monographs, 54:187-211.

IKEDA, H., Y. ONo, M. BABA, I. DOI, AND T. Iwamoto. 1982. Ranging and activity patterns of three nocturnal viverrids in Omo National Park, Ethiopia. African Journal of Ecology, 20:179-186.

IKEDA, H., M. IZAWA, M. BABA, M. TAKeISHI, T. Dor, AND Y. ONO. 1983. Range size and activity pattern of three nocturnal carnivores in Ethiopia by radiotelemetry. Journal of Ethology, 1:109-111.

Kavanau, J. L., And J. Ramos. 1972. Twilights and onset and cessation of carnivore activity. The Journal of Wildlife Management, 36:653-657.

. 1975. Influences of light on activity and phasing of carnivores. The American Naturalist, 109:391-418.

KENWARD, R. 1990. Ranges IVm. Biotrack, Wareham, United Kingdom, $33 \mathrm{pp}$.

KufELd, R. C., D. C. Bowden, ANd J. M. SipereK, JR. 1987. Evaluation of a telemetry system for measuring habitat usage in mountainous terrain. Northwest Science, 61:249-256.

KufNer, M. B., AND S. MoReno. 1989. Abundacia y amplitud de los desplazamientos de Apodemus sylvaticus en cuatro biotopos de Doñana que difieren en cobertura vegetal. Doñana, Acta Vertebrata, 16 179-181.

LEVINS, R. 1968. Evolution in changing environments. Princeton University Press, Princeton, New Jersey, $120 \mathrm{pp}$.

Liver, F., AND J. J. RoEder. 1987. Encyclopédie des carnivores de France. La genette (Genetta genetta, Linnaeus, 1758). Societe Française pour l'Etude et la Protection des Mammiferes, 17:1-33.

Lode, T., I. Lechat, and D. Le JaCQues. 1991. Le régime alimentaire de la genette en limite nord-ouest de son aire de répartition. Revue d'Ecologie (Terre and Vie), 46:339-348.

MACDONALD, D. W. 1983. The ecology of carnivore social behaviour. Nature, 301:379-384.

MAdDock, A. H., AND M. R. PERrin. 1993. Spatial and temporal ecology of an assemblage of viverrids in Natal, South Africa. Journal of Zoology (London), 229:227-287.

MCNAB, B. K. 1963. Bioenergetics and the determination of home range size. The American Naturalist, 97:11-17.

$\mathrm{MECH}$, L. D. 1983. Handbook of animal radio-tracking. University of Minnesota Press, Minneapolis, $107 \mathrm{pp}$.
Nams, V. O. 1989. Effects of radiotelemetry error on sample size and bias when testing for habitat selection. Canadian Journal of Zoology, 67:1631-1636.

Neu, C. W., C. R. Byers, ANd J. M. PeCK. 1974. A technique for analysis of utilization-availability data. The Journal of Wildlife Management, 38:541-545.

PALOMARES, F. 1993. Immobilization of common genets, Genetta genetta, with a combination of ketamine and xylazine. Journal of Wildlife Diseases, 29:174176.

Palomares, F, and M. Delibes. 1988. Time and space use by two common genets (Genetta genetta) in the Doñana National Park, Spain. Journal of Mammalogy, 69:635-637.

- 1991a. Assessing three methods to estimate daily activity patterns in radio-tracked mongooses. The Journal of Wildlife Management, 55:698-700.

. 1991b. Alimentación del meloncillo Herpestes ichneumon y de la gineta Genetta genetta en la Reserva Biológica de Doñana, S.O. de la Península Ibérica. Doñana, Acta Vertebrata, 18:5-20.

- 1992a. An evaluation of techniques for capturing and radio-collaring large grey mongooses. South African Journal of Wildlife Research, 22:7679.

1992b. Data analysis design and potential bias in radio-tracking studies of animal habitat use. Acta Oecologica, 13:221-226.

-. In press. Key habitats for Egyptian mongooses in Doñana National Park, southwestern Spain. The Journal of Applied Ecology.

Reynolds, T. D., AND J. W. Laundré. 1990. Time intervals for estimating pronghorn and coyote home ranges and daily movements. The Journal of Wildlife Management, 54:316-322.

Rogers, P. M., AND K. MYERs. 1980. Animal distributions, landscape classification and wildlife management, Coto Doñana, Spain. The Journal of Applied Ecology, 17:545-565.

SIEGEL, S. 1956. Nonparametric statistics for the behavioral sciences. McGraw-Hill Book Company, New York, 312 pp.

SPENCER, W. D., AND R. H. BarretT. 1984. An evaluation of the harmonic mean measure for defining carnivore activity areas. Acta Zoologica Fennica, 171:255-259.

Swihart, R. K., AND N. A. Slade. 1985a. Influence of sampling interval on estimates of home-range size. The Journal of Wildlife Management, 49:10191025.

- 1985b. Testing for independence of observation in animal movements. Ecology, 66:11761184

VALVERdE, J. A. 1960. Vertebrados de las Marismas del Guadalquivir. Archivos del Instituto de Aclimatación de Almería, 9:1-168.

WASER, P. M. 1980. Small nocturnal carnivores: ecological studies in the Serengeti. African Journal of Ecology, 18:167-185.

White, G. C., AND R. A. Garrotr. 1986. Effects of biotelemetry triangulation error on detecting habitat selection. The Journal of Wildlife Management, 50: $509-513$

Submitted 15 July 1993. Accepted 30 December 1993

Associate Editor was Stephen H. Vessey. 